DOI: https://doi.org/10.31933/jimt.v2i6

Received: 13 Juni 2021, Revised: 25 Juni 2021, Publish: 31 Juli 2021

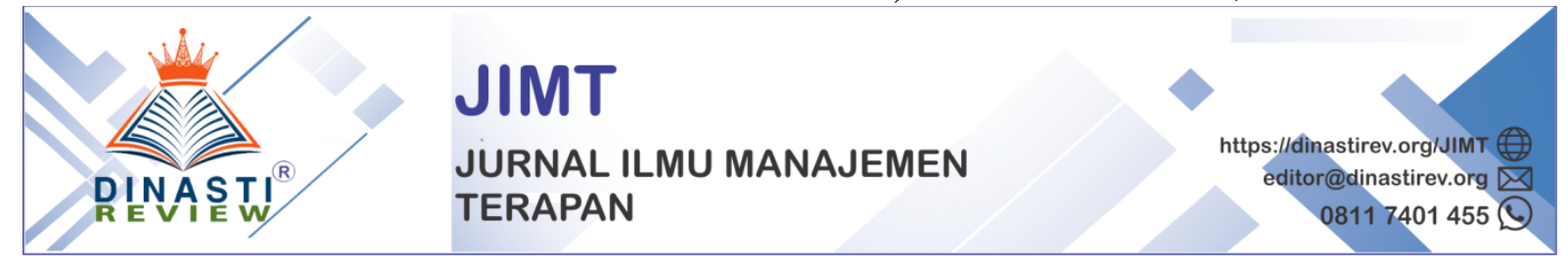

\title{
DETERMINASI KEPUTUSAN PEMBELIAN DAN PEMBELIAN ULANG (LITERATURE REVIEW MANAJEMEN PEMASARAN)
}

\author{
Dandy Hafidh Fauzi \\ ${ }^{1}$ Student of Magister Management, Universitas Mercu Buana Jakarta, \\ dandyfauzi@gmail.com, 43213120052@student.mercubuana.ac.id
}

\begin{abstract}
Abstrak: Penelitian terdahulu yang relevan sangat penting dalam suatu penelitian atau artikel ilmiah. Penelitian terdahulu yang relevan berfungsi untuk memperkuat teori dan fenomena hubungan antar variable. Artikel ini mereview variabel yang mempengaruhi Keputusan Pembelian dan Pembelian Ulang terhadap smarthphone Samsung, maka dilakukan review penelitian terdahulu. Hasil pra riset menunjukkan bahwa diduga kualitas produk dan harga memiliki pengaruh baik secara langsung maupun tidak langsung terhadap keputusan pembelian dan pembelian ulang pada smartphone Samsung.
\end{abstract}

Kata Kunci: Kualitas Produk, Harga, Keputusan Pembelian, dan Pembelian Ulang

\section{PENDAHULUAN}

\section{Latar Belakang Masalah}

Pada era teknologi informasi saat ini, perkembangan teknologi komunikasi semakin berkembang pesat. Hal ini dibuktikan dengan tersedianya berbagai teknologi komunikasi yang memudahkan masyarakat dalam berkomunikasi. Dan salah satu alat teknologi komunikasi yang banyak digunakan adalah smartphone.

Di Indonesia penjualan smartphone juga mengalami fluktuasi penjualan. Berdasarkan laporan International Data Corporation (IDC), kuartal 2 dari tahun 2017 sampai 2020, terdapat berapa penurunan dan peningkatan beberapa produk smartphone. Smatphone yang terus mengalami penurunan adalah samsung.

Tahun 2017 ke tahun 2018 mengalami penurunan sebesar 5\% yaitu dari 32\% menjadi 27\%. Selanjutnya kuartal 2 tahun 2018 ke kuartal 2 tahun 2019 turun tipis sebesar $0.1 \%$ yaitu dari 27\% menjadi 26.9\%. Pada kuartal 2 tahun 2019 sampai dengan kuartal 2 tahun 2020 dapat dilihat Samsung masih mengalami penurunan pangsa pasar dengan market share tahun 2019 sebesar $26.9 \%$ turun menjadi $18.7 \%$ sehingga menunjukkan penurunan sebesar $8.2 \%$. Sehingga hal ini mengakibatkan Samsung tergeser ke posisi ke 3 dari posisi puncak pada tahun 2020, dimana posisi pertama dan kedua di raih oleh Vivo dan Oppo. 
Penurunan penjualan secara terus menerus pada samartphone samsung ini menjadikan kasus ini menarik untuk diteliti. Banyaknya brand smartphone yang memiliki kualitas dan harga yang terjangkau menimbulkan smartphone samsung mengalami kendala yang besar dalam penjualannya. Oleh karena itu perlu di cari faktor-faktor apa saja yang mempengaruhi keputusan pembelian konsumen dan Pembalian Ulang terhadap smartphone Samsung.

Artikel ini membahas pengaruh Kuslitas Produk dan Harga terhadap Keputusan Pembelian dan dampaknya terhadap Pembelian Ulang. Dimana, tidak semua faktor yang mempengaruhi Keputusan Pembelian dan Pembelian Ulang pada artikel ini, ini hanya sebagian kecil saja yang akan di kaji dan di review.

Secara rinci tujuan dari penulisan "Literature Review Paper" ini adalah mengetahui pengaruh atau hubungan antara variabel eksogen Kualitas Produk dan Harga terhadap variabel endogen Keputusan Pembelian dan Pembelian Ulang.

1) Pengaruh atau hubungan Kualitasa Produk terhadap Keputusan Pembelian

2) Pengaruh atau hubungan Kualitas Produk terhadap terhadap Pembelian Ulang

3) Pengaruh atau hubungan Harga terhadap Keputusan Pembelian

4) Pengaruh atau hubungan Harga terhadap Pembelian Ulang

5) Pengaruh atau hubungan Keputusan Pembelian terhadap Pembelian Ulang

\section{KAJIAN TEORI}

\section{Kualitas Produk}

Menurut (Kotler \& Amstrong, 2012b) kualitas produk merupakan kemampuan suatu produk melakukan fungsinya, hal ini termasuk masa kegunaan produk, keandalan, ketepatan, kemudahan dalam mengoperasikan dan membetulkan, nilai atribut lainnya. Kualitas produk dapat ditinjau dari sudut pandang internal perusahaan maupun sudut pandang eksternal perusahaan. (Kotler \& Amstrong, 2012a) menjelaskan bahwa dalam ilmu pemasaran kualitas produk diukur dari sudut pandang eksternal yaitu melalui persepsi pembeli.

Menurut (Perreault et al., 2017) kualitas produk merupakan kemampuan produk untuk memberikan kepuasan pada kebutuhan dan keperluan pelanggan. Definisi tersebut berfokus pada pelanggan serta berfokus pada bagaimana pelanggan berpikir bahwa produk tersebut sesuai dengan tujuan mereka.

Menurut (Schiffman \& Kanuk, 2010) kualitas produk dapat didefinisikan sebagai seberapa konsisten produk yang dihasilkan dapat memenuhi pengharapan dan kebutuhan internal dan eksternal pelanggan.

Variabel Kualitas Produk ini sudah banyak di teliti oleh peneliti sebelumnya di antaranya adalah (Brata et al., 2017), (Anggita \& Ali,2017), (Suhaily \& Darmoyo, 2017), (Tawas \& Pandensolang, 2015), (Ali, 2019b), (Ikhsani \& Ali, 2017), dan lain-lain.

\section{Harga}


Menurut (Kotler \& Amstrong, 2012a) dalam arti yang sempit harga adalah jumlah yang ditagihkan atas suatu produk dan jasa. Lebih luas lagi, harga adalah jumlah semua nilai yang diberikan oleh pelanggan untuk mendapatkan keuntungan dari memiliki atau menggunakan suatu produk atau jasa.

Menurut (Tjiptono, 2002) secara sederhana istilah harga dapat diartikan sebagai jumlah uang (satuan moneter) dan atau aspek lain (non moneter) yang mengandung utilitas atau kegunaan tertentu yang diperlukan untuk mendapatkan suatu jasa, utilitas merupakan atribut atau faktor yang berpotensi memuaskan kebutuhan dan keinginan tertentu.

Harga menurut (Swastha, Basu Dharmmesta, 2014) adalah sejumlah uang yang dibutuhkan untuk mendapatkan sejumlah kombinasi dari produk dan pelayanannya. dari definisi tersebut, dapat kita ketahui bahwa harga yang dibayar oleh pembeli itu sudah termasuk pelayanan yang diberikan oleh penjual, bahkan penjual juga menginginkan sejumlah keuntungan dari harga tersebut, harga yang ditetapkan pada dasarnya disesuaikan dengan apa yang menjadi pengharapan produsen.

Variabel Harga ini sudah banyak di teliti oleh peneliti sebelumnya di antaranya adalah (Yunita \& Ali, 2017), (Estu Mahanani, 2018), (Novansa \& Ali, 2017), (Yunita \& Ali, 2017), (Palma \& Andjarwati, 2016), dan lain-lain.

\section{Keputusan Pembelian}

Keputusan pembelian menurut (Tjiptono, 2002) adalah sebuah proses dimana konsumen mengenal masalahnya, mencari informasi mengenai produk atau merek tertentu dan mengevaluasi seberapa baik masing-masing alternatif tersebut dapat memecahkan masalahnya, yang kemudian mengarah kepada keputusan pembelian.

Menurut (Kotler \& Keller, 2016) keputusan pembelian adalah keputusan konsumen untuk memutuskan membeli setelah mengevaluasi beberapa faktor seperti merek, tempat pembelian, kuantitas yang akan dibeli, waktu pembelian, serta metode pembayaran yang dapat dilakukan.

(Schiffman \& Kanuk, 2010) mengatakan bahwa menurut pemahaman yang paling umum keputusan pembelian adalah seleksi terhadap dua pilihan alternatif atau lebih. Dengan kata lain, pilihan alternatif harus tersedia bagi seseorang ketika mengambil keputusan. Pilihan alternatif yang dihadapi bisa berupa melakukan pembelian atau tidak, pilihan antara berbagai merek, pilihan lokasi dan tempat pembelian, dan sebagainya.

Variabel Keputusan Pembelian sudah banyak di teliti oleh peneliti sebelumnya di antaranya adalah (Brata et al., 2017), (Estu Mahanani, 2018), (Novansa \& Ali, 2017), (Yunita \& Ali, 2017), (Tawas \& Pandensolang, 2015), dan lain-lain.

\section{Pembelian Ulang}

Pembelian Ulang menurut (Kotler \& Keller, 2016) adalah tindakan konsumen pasca pembelian, terjadinya kepuasan atau ketidakpuasan pasca pembelian konsumen terhadap 
suatu produk akan mempengaruhi perilaku selanjutnya, jika konsumen puas maka akan menunjukan kemungkinan yang lebih tinggi untuk membeli kembali produk tersebut.

Pembelian Ulang atau Pembelian Kembali adalah perilaku yang muncul sebagai respons terhadap suatu objek. Minat membeli kembali menunjukkan keinginan pelanggan untuk masa depan. Perilaku pembelian kembali sering dikaitkan dengan Kualitas Produk. Namun, ada perbedaan di antara keduanya. Jika loyalitas mencerminkan komitmen psikologis terhadap merek tertentu, maka perilaku pembelian kembali semata-mata menyangkut pembelian merek tertentu yang sama secara berulang kali (Tjiptono, 2002). Semakin banyak pengalaman yang dimiliki seseorang terhadap suatu merek atau produk, semakin banyak pembelian berulang yang terjadi pada produk yang mendapat evaluasi yang baik.

Variabel Pembelian Ulang sudah banyak di teliti oleh peneliti sebelumnya di antaranya adalah (Hidayat et al., 2020), (Nguyen et al., 2019), (Yohanda et al., 2019), (AlShatti, 2014), (Palma \& Andjarwati, 2016), dan lain-lain.

\section{METODE PENULISAN}

Metode penulisan artikel ilmiah ini adalah dengan metode kualitatif dan studi literature atau Library Research. Mengkaji Buku-buku literature sesuai dengan teori yang di bahas khusunya di lingkup Manajemen Pemasaran. Disamping itu menganalisis artikel-artikel ilmiah yang bereputasi dan juga artikel ilmiah dari jurnal yang belum bereputasi. Semua artikel ilmiah yang di citasi bersumber dari Mendeley dan Scholar Google.

Dalam penelitian kualitatif, kajian pustaka harus digunakan secara konsisten dengan asumsi-asumsi metodologis. Artinya harus digunakan secara induktif sehingga tidak mengarahkan pertanyaan-pertanyaan yang diajukan oleh peneliti. Salah satu alasan utama untuk melakukan penelitian kualitatif yaitu bahwa penelitian tersebut bersifat eksploratif, (Ali \& Limakrisna, 2013).

Selanjutnya dibahas secara mendalam pada bagian yang berjudul" Pustaka Terkait" (Related Literature) atau Kajian pustaka( "Review of Literature"), sebagai dasar perumusan hipotesis dan selanjutnya akan menjadi dasar untuk melakukan perbandingan dengan hasil atau temuan-temuan yang terungkap dalam penelitian, (Ali \& Limakrisna, 2013).

\section{PEMBAHASAN}

\section{Pengaruh Kualitas Produk terhadap Keputusan Pembelian}

Menurut (Kotler \& Amstrong, 2012b) kualitas produk merupakan kemampuan suatu produk melakukan fungsinya, hal ini termasuk masa kegunaan produk, keandalan, ketepatan, kemudahan dalam mengoperasikan dan membetulkan, nilai atribut lainnya. Semakin baik kualitas suatu produk, maka akan memberikan pengaruh terhadap keputusan pembelian suatu produk.

Menurut (Brata et al., 2017) kualitas produk menunjukkan pengaruh yang positif terhadap keputusan pembelian. Dalam kualitas produk terdapat beberapa dimensi yang 
membangunnya. Kinerja produk yang baik, daya tahan yang bagus, kesesuain produk terhadap penggunaanya, fitur yang lengkap, reliabilitas dan unsur estetika yang sesuai akan meberikan nilai yang positif terhadap kualitas produk dan akan memberikan pengaruh yang baik terhadap keputusan pembelian (Perreault et al., 2017).

Pengaruh variabel Kualitas Produk terhadap Keputusan Pembelian sudah banyak di teliti oleh peneliti sebelumnya di antaranya adalah (Yunita \& Ali, 2017), (Estu Mahanani, 2018), (Brata et al., 2017), (Suhaily \& Darmoyo, 2017), (Ikhsani \& Ali, 2017), (Suhaily \& Darmoyo, 2017), (Yunita \& Ali, 2017), dan (Tawas \& Pandensolang, 2015).

\section{Pengaruh Kualitas Produk terhadap Pembelian Ulang}

Menurut (Perreault et al., 2017) kualitas produk merupakan kemampuan produk untuk memberikan kepuasan pada kebutuhan dan keperluan pelanggan. Definisi tersebut berfokus pada pelanggan serta berfokus pada bagaimana pelanggan berpikir bahwa produk tersebut sesuai dengan tujuan mereka.

Menurut (Schiffman \& Kanuk, 2010) mngungkapkan bahwa kualitas produk berkaitan dengan seberapa konsisten produk yang dihasilkan dapat memenuhi pengharapan dan kebutuhan internal dan eksternal pelanggan.

Dalam penelitian (Hidayat et al., 2020) menunjukkan hubungan yang positif antara kualitas produk terhadap pembelian ulang. Hal ini menunjukkan bahwa memang kualitas produk yang semakin baik akan memberikan dampak yang baik terhadap minat konsumen untuk mekalukan pembelian kembali.

Pengaruh variabel Kualitas Produk terhadap Pembelian Ulang sudah banyak di teliti oleh peneliti sebelumnya di antaranya adalah (Hidayat et al., 2020), (Ali, 2019b), (Nguyen et al., 2019), (Suhaily \& Darmoyo, 2017), (Han \& goleman, daniel; boyatzis, Richard; Mckee, 2019), dan (Palma \& Andjarwati, 2016).

\section{Pengaruh Harga terhadap Keputusan Pembelian}

Menurut (Tjiptono, 2002) secara sederhana istilah harga dapat diartikan sebagai jumlah uang (satuan moneter) dan atau aspek lain (non moneter) yang mengandung utilitas atau kegunaan tertentu yang diperlukan untuk mendapatkan suatu jasa, utilitas merupakan atribut atau faktor yang berpotensi memuaskan kebutuhan dan keinginan tertentu.

Harga merupakan salah satu faktor yang dirasa akan memberikan dampak terhadap keputusan konsumen dalam melakukan pembelian suatu produk (Swastha, Basu Dharmmesta, 2014). Harga yang ditetapkan pada dasarnya disesuaikan dengan apa yang menjadi pengharapan produsen dan kemampuan konsumen.

Dalam penelitian (Yunita \& Ali, 2017) menunjukkan hubungan yang positif terhadap keputusan pembelian. Artinya semakin baik harga suatu produk makan akan semakin mempengaruhi keputusan konsuman dalam melakukan pembelian produk. 
Pengaruh variabel Harga terhadap Keputusan Pembelian sudah banyak di teliti oleh peneliti sebelumnya di antaranya adalah (Yunita \& Ali, 2017), (Estu Mahanani, 2018), (Brata et al., 2017), (Suhaily \& Darmoyo, 2017), (Suhaily \& Darmoyo, 2017), (Novansa \& Ali, 2017), (Suhaily \& Darmoyo, 2017), dan (Yunita \& Ali, 2017).

\section{Pengaruh Harga terhadap Pembelian Ulang}

Menurut (Kotler \& Amstrong, 2012a) dalam arti yang sempit harga adalah jumlah yang ditagihkan atas suatu produk dan jasa. Lebih luas lagi, harga adalah jumlah semua nilai yang diberikan oleh pelanggan untuk mendapatkan keuntungan dari memiliki atau menggunakan suatu produk atau jasa. Ketika harga dirasa sesuai dengan harapan konsumen makan akan menarik minat konsumen untuk membeli produk kembali.

Dalam penelitian (Paramananda \& Sukaatmaja, 2018), terdapat hubungan yang positif terhadap pembelian ulang. Hal ini menandakan semakin baik suatu harga makan akan memberiakan dampak yang besar bagi pembelian ulang suatu produk. Proporsi harga yang ditentukan biasanya sebanding dengan kualitas produk yang ditawarkan. Dengan demikin maka akan memberikan kesan positif pada suatu produk dan membuat konsumen dapat melakukan pembelian kembali pada suatu produk.

Pengaruh variabel Harga terhadap Pembelian Ulang sudah banyak di teliti oleh peneliti sebelumnya di antaranya adalah (Yohanda et al., 2019), (Korowa et al., 2018), (Al-Shatti, 2014), dan (Palma \& Andjarwati, 2016).

\section{Pengaruh Keputusan Pembelian terhadap Pembelian Ulang}

Keputusan pembelian menurut (Tjiptono, 2002) adalah sebuah proses dimana konsumen mengenal masalahnya, mencari informasi mengenai produk atau merek tertentu dan mengevaluasi seberapa baik masing-masing alternatif tersebut dapat memecahkan masalahnya, yang kemudian mengarah kepada keputusan pembelian.

Dalam penelitian (Ali, 2019b) menunjukkan pengaruh yang positif antara keputusan pembelian terhadap pembelian ulang. Pembelian Ulang adalah tindakan konsumen pasca pembelian, terjadinya kepuasan atau ketidakpuasan pasca pembelian konsumen terhadap suatu produk akan mempengaruhi perilaku selanjutnya, jika konsumen puas maka akan menunjukan kemungkinan yang lebih tinggi untuk membeli kembali produk tersebut (Kotler \& Keller, 2016).

Pengaruh variabel Harga terhadap Pembelian Ulang sudah banyak di teliti oleh peneliti sebelumnya di antaranya adalah (Ali, 2019b), (Nguyen et al., 2019), (Alexi et al., 2016), dan (Suryana \& Dasuki, 2013).

\section{Conceptual Framework}

Berdasarkan rumusan masalah penulisan artikel ini dan kajian studi literature review baik dari buku dan artikel yang relevan, maka di perolah rerangka artikel ini seperti di bawah ini. 


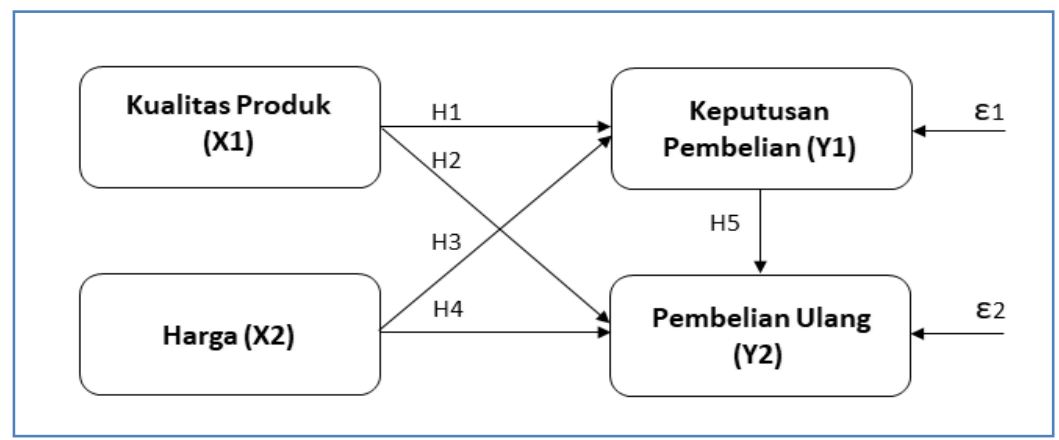

Gambar: Conceptual Framework

Kualitas Produk dan Harga memiliki hubungan dan berpengaruh terhadap Keputusan Pembelian dan Pembelian Ulang baik secara langsung maupun tidak langsung.

Selain dari variabel Kualitas Produk dan Harga yang mempengaruhi Keputusan Pembelian dan Pembelian Ulang, masih banyak variabel lain yang mempengaruhinya, di antaranya adalah variabel:

1) Promosi dan Lokasi: (Ali, Evi, et al., 2018), (Prihartono \& Ali, 2020), (Richardo et al., 2020), (Mappesona et al., 2020), (Sulistiorini \& Ali, 2017), (Hairiyah \& Ali, 2017), (Ali, Narulita, et al., 2018a), and (Brata et al., 2017);

2) Citra Merek: (Ali et al., 2016), (M \& Ali, 2017), (Ali \& Mappesona, 2016), (Ali, Narulita, et al., 2018a), (Novansa \& Ali, 1926), and (Toto Handiman \& Ali, 2019).

3) Kesadaran Merek: (Toto Handiman \& Ali, 2019), (Novansa, Hafizh, Ali, 2017), (Ali, 2019a), and (Sivaram et al., 2020);

4) Pilihan pelanggan: (Indarsin \& Ali, 2017), (Ali \& Mappesona, 2016), (Ali, Narulita, et al., 2018b), (Mulyani et al., 2020), (Sulistiorini \& Ali, 2017), (Mansur \& Ali, 2017);

5) Lingkungan: (Ali \& Sardjijo, 2017), (Desfiandi et al., 2017), (Richardo et al., 2020), (Yunita \& Ali, 2017), (Ali, 2019a), (Brata et al., 2017), (Anggita \& Ali, 2017), (Thanh Nguyen et al., 2019), (Novansa \& Ali, 1926), (Mappesona et al., 2020) (Ali, Evi, et al., 2018), (Ali, Narulita, et al., 2018a).

\section{KESIMPULAN DAN SARAN}

\section{Kesimpulan}

Berdasarkan rumusan artikel, hasil dan pembahasan, maka dapat di di rumuskan hipotesis untuk riset selanjutnya:

1. Kualitas produk berpengaruh terhadap keputusan pembelian

2. Kualitas produk berpengaruh terhadap pembelian ulang

3. Harga berpengaruh terhadap keputusan pembelian.

4. Harga berpengaruh terhadap pembelian ulang

5. Keputusan pembelian berpengaruh terhadap pembelian ulang.

\section{Saran}


Berdasarkan Kesimpulan di atas, maka saran pada artikel ini adalah bahwa masih banyak factor lain yang mempengaruhi Keputusan Pembelian dan Pembelian Ulang, selain dari Kualitas Produk dan Harga. Oleh karena itu masih di perlukan kajian yang lebih lanjut untuk mencari faktor-faktor lain apa saja yang dapat memepengaruhi Keputusan Pembelian dan Pembalian Ulang selain yang di teliti pada arikel ini.

\section{DAFTAR PUSTAKA}

Al-Shatti, A. S. (2014). The Impact of Public Expenditures on Economic Growth in Jordan. International Journal of Economics and Finance, 6(10). https://doi.org/10.5539/ijef.v6n10p157

Alexi, M., Zulkarnain, Z., \& Musfar, T. (2016). Pengaruh Brand Image Dan Product Design Terhadap Purchase Decision Dan Repurchase Intention Pada Produk Sepatu Futsal Merek Specs Di Kota Pekanbaru. Jurnal Online Mahasiswa Fakultas Ekonomi Universitas Riau, 4(1), 350-363.

Ali, H. (2019a). Building Repurchase Intention and Purchase Decision: Brand Awareness and Brand Loyalty Analysis (Case Study Private Label Product in Alfamidi Tangerang). Saudi Journal of Humanities and Social Sciences. https://doi.org/10.36348/sjhss.2019.v04i09.009

Ali, H. (2019b). Purchase Decision and Repurchase Models: Product Quality and Process Analysis (Case Study of House Ownership Credit Financing in Permata Sharia Bank Jakarta). Scholars Bulletin. https://doi.org/10.36348/sb.2019.v05i09.006

Ali, H., Evi, N., \& Nurmahdi, A. (2018). The Influence of Service Quality , Brand Image and Promotion on Purchase Decision at MCU Eka Hospital. Business and Management Studies. https://doi.org/10.21276/sjbms.2018.3.1.12

Ali, H., Limakrisna, N., \& Jamaluddin, S. (2016). Model of customer satisfaction: The empirical study at Bri in Jambi. International Journal of Applied Business and Economic Research.

Ali, H., \& Mappesona, H. (2016). Build brand image: Analysis Service Quality and Product Quality (case study at Giant Citra Raya). International Journal of Economic Research.

Ali, H., Narulita, E., \& Nurmahdi, A. (2018b). The Influence of Service Quality, Brand Image and Promotion on Purchase Decision at MCU Eka Hospital. Saudi Journal of Business and Management Studies. https://doi.org/10.21276/sjbms.2018.3.1.12

Ali, H., \& Sardjijo. (2017). Integrating Character Building into Mathematics and Science Courses in Elementary School. International Journal of Environmental and Science Education. https://doi.org/10.1007/s10648-016-9383-1

Anggita, R., \& Ali, H. (2017). The Influence of Product Quality, Service Quality and Price to Purchase Decision of SGM Bunda Milk (Study on PT. Sarihusada Generasi Mahardika Region Jakarta, South Tangerang District). Scholars Bulletin. https://doi.org/10.21276/sb

Brata, B. H., Husani, S., \& Ali, H. (2017). The Importance of Quality Products, Price, Promotion, and Location to Product Purcese Decision on Nitchi At PT. Jaya Swarasa Agung in Central Jakarta. Saudi Journal of Business and Management Studies. https://doi.org/10.21276/sjbms 
Desfiandi, A., Desfiandi, A., \& Ali, H. (2017). Composite Stock Price Index (IHSG) Macro Factor in Investment in Stock (Equity Funds). International Journal of Economics and Financial Issues.

Estu Mahanani. (2018). Dan Gaya Hidup Terhadap Keputusan Pembelian Produk. KraithHumaniora, 2(2), 53-61.

Hairiyah, S., \& Ali, H. (2017). Customer Decision Analysis in Taking Multipurpose Loan: Promotions , Locations and Credit Procedures ( A Case of the Bank " PQR Jakarta "). Saudi Journal of Business and Management Studies. https://doi.org/10.21276/sjbms.2017.2.3.6

Hamdan, H., \& Paijan, P. (2020). Utilitarian values and hedonic values of women coffee lovers. Dinasti International Journal of Education Management and Social Science, 2(2), 310-322. https://doi.org/10.31933/dijemss.v2i2.666

Hamdan, H., \& Yuliantini, T. (2021). Purchase behavior : online tour package. Dinasti International Journal of Management Science, 2(3), 420-434. https://doi.org/10.31933/dijms.v2i3.704

Han, E. S., \& goleman, daniel; boyatzis, Richard; Mckee, A. (2019). 済無No Title No Title. Journal of Chemical Information and Modeling, 53(9), 1689-1699.

Hidayat, D., Bismo, A., \& Basri, A. R. (2020). the Effect of Food Quality and Service Quality Towards Customer Satisfaction and Repurchase Intention (Case Study of Hot Plate Restaurants). Manajemen Bisnis, 10(1), 1. https://doi.org/10.22219/jmb.v10i1.11913

Indarsin, T., \& Ali, H. (2017). Attitude toward Using m-Commerce: The Analysis of Perceived Usefulness Perceived Ease of Use, and Perceived Trust: Case Study in Ikens Wholesale Trade, Jakarta - Indonesia. Saudi Journal of Business and Management Studies. https://doi.org/10.21276/sjbms.2017.2.11.7

Kotler, P., \& Amstrong, G. (2012a). Marketing. In BMC Public Health.

Kotler, P., \& Amstrong, G. (2012b). Principles of Marketing Global. In USE: Pearson Education.

Kotler, P., \& Keller, K. L. (2016). Marketing Mangement. In Pearson Edition Limited.

M, A., \& Ali, H. (2017). MODEL KEPUASAN PELANGGAN: ANALISIS KUALITAS PRODUK DAN KUALITAS LAYANAN TERHADAP CITRA MEREK PADA GIANT CITRA RAYA JAKARTA. Jurnal Manajemen. https://doi.org/10.24912/jm.v21i3.254

Mansur, S., \& Ali, H. (2017). Impact of customer engagement to reputation of the Bri Syariah Indonesia. International Journal of Economic Research.

Mappesona, H., Ikhsani, K., \& Ali, H. (2020). Customer purchase decision model, supply chain management and customer satisfaction: Product quality and promotion analysis. International Journal of Supply Chain Management.

Mulyani, S. R., Ridwan, M., \& Ali, H. (2020). Model of human services and resources: The improvement efforts of Silungkang restaurant attractiveness on consumers. Talent Development and Excellence.

Nguyen, P. T., Ali, H., \& Hudaya, A. (2019). Model Buying Decision and Repeat Purchase: 
Product Quality Analysis. Dinasti International Journal of Management Science, 1(1), 2686-5211. https://doi.org/10.31933/DIJMS

Novansa, Hafizh, Ali, H. (2017). Purchase Decision Model: Analysis of Brand Image, Brand Awareness and Price (Case Study SMECO Indonesia SME products). Saudi Journal of

Palma, M. A., \& Andjarwati, A. L. (2016). PENGARUH KUALITAS PRODUK, KEMUDAHAN, DAN HARGA TERHADAP NIAT BELI ULANG DENGAN KEPUASAN SEBAGAI VARIABEL INTERVENING (Studi Pada Pelanggan Produk Fashion Melalui Toko online di Surabaya). Jurnal Riset Ekonomi Dan Manajemen, 16(1), 84. https://doi.org/10.17970/jrem.16.60106.id

Perreault, W. D., Cannon, J. P., \& Mccarthy, E. J. (2017). Un enfoque de planificación de la estrategia de marketing. In Essentials of Marketing A Marketing Strategy Planning Approach.

Prihartono, \& Ali, H. (2020). The promises ethics and marketing concept strategy as a competitive advantage on private higher education (A survey on perception of product attributes and promotion mix in Indonesia). Talent Development and Excellence.

Richardo, Hussin, M., Bin Norman, M. H., \& Ali, H. (2020). A student loyalty model: Promotion, products, and registration decision analysis-Case study of griya english fun learning at the tutoring institute in wonosobo central Java. International Journal of Innovation, Creativity and Change.

Schiffman, L. G., \& Kanuk, L. L. (2010). Consumer Behavior 10th Edition. Pearson Education.

Sivaram, M., Munawar, N. A., \& Ali, H. (2020). DETERMINATION OF PURCHASE INTENT DETERMINATION OF PURCHASE INTENTION THROUGH BRAND AWARENESS AND PERCEIVED QUALITY (Case Study: For consumers PT. Sentosa Santosa Finance Tangerang area). Dinasti International Journal of Management Science. https://doi.org/10.31933/dijms.v1i2.71

Suhaily, L., \& Darmoyo, S. (2017). Effect of product quality, perceived price and brand image on purchase decision mediated by customer trust (study on japanese brand electronic product). Jurnal Manajemen, 21(2), 179-194. https://doi.org/10.24912/jm.v21i2.230

Sulistiorini, M. S., \& Ali, H. (2017). Customer satisfaction model: Product analysis, price, promotion and distribution (case study at PT Integrasia Utama). International Journal of Applied Business and Economic Research.

Suryana, P., \& Dasuki, E. S. (2013). Analisis Faktor yang Mempengaruhi Keputusan Pembelian dan Implikasinya pada Minat Beli Ulang. Trikonomika, 12(2), 190. https://doi.org/10.23969/trikonomika.v12i2.479

Swastha, Basu Dharmmesta, T. handoko. (2014). Manajemen Pemasaran. In PBFE Yogyakarta.

Tawas, H., \& Pandensolang, J. (2015). Pengaruh Diferensiasi, Kualitas Produk Dan Ekuitas Merek Terhadap Keputusan Pembelian Coca-Cola Pada Pt. Bangun Wenang Beverges Company Di Manado. Jurnal Riset Ekonomi, Manajemen, Bisnis Dan Akuntansi, 3(3), 1113-1124.

Thanh Nguyen, P., Ali, H., \& Agung Hudaya. (2019). MODEL BUYING DECISION AND 
REPEAT PURCHASE: PRODUCT QUALITY ANALYSIS (Case Study of Bank Permata Syariah Jakarta KPR Financing Customers). Dinasti International Journal of Management Science. https://doi.org/10.31933/dijms.v1i1.29

Tjiptono, F. (2002). Strategi Pemasaran. Andi.

Toto Handiman, U., \& Ali, H. (2019). The Influence of Brand Knowledge and Brand Relationship On Purchase Decision Through Brand Attachment. In International Journal of Business Marketing and Management (IJBMM).

Yohanda, A. R., Masdupi, E., \& Engriani, Y. (2019). The Influence of Promotion, Perceived Ease of Use, and Price Toward Repurchase Intention Transportation Services Go-jek on Students in Universitas Negeri Padang. Jurnal Kajian Manajemen Dan Wirausaha, 1(1), 2019.

Yunita, D., \& Ali, H. (2017). Model of Purchasing Decision ( Renting ) of Generator Set: Analysis of Product Quality, Price an Service at PT . Hartekprima Listrindo.

Economics, Business and Management. https://doi.org/10.21276/sjebm.2017.4.11.12 